\title{
Failed Attempt to Break Up the Oligopoly in Sovereign Credit Rating Market after Financial Crises
}

Alicja Malewska

ABSTRACT

For decades, the credit rating market has been dominated by three major agencies (Moody's, S\&P and Fitch Ratings). Their oligopolistic dominance is especially strong in sovereign credit ratings industry, where they hold a collective global share of more than $99 \%$. Global financial crisis and the Eurozone sovereign debt crisis exposed serious flaws in rating process and forced public authorities to act. This study investigates effectiveness of new regulations adopted in the United States and in the European Union after financial crises in terms of reducing oligopolistic dominance of the "Big Three" in sovereign credit ratings market. The study applies descriptive statistical analysis of economic indicators describing concentration rate in a market, as well as content analysis of legal acts and case study methodology. Analysis shows that the Dodd-Frank reform and new European rules on supervision of credit rating agencies were not effective enough and did not lead to the increased competition in the market. The evidence from this study is explained using two alternative perspectives - economic theory of natural oligopoly and hegemonic stability theory coming from international relations field.

KEY WORDS: $\quad$ Credit rating agencies, oligopoly, sovereign ratings, financial crisis.

JEL Classification: F34, F59, G15, G28.

Jesuit University Ignatianum in Krakow, Poland

\section{Introduction}

Credit rating agencies (CRAs) have been present in financial markets for more than a century. However, events of the recent years, including the global financial crisis, have substantially changed their situation. Agencies suddenly found themselves in the limelight, although this attention was rarely positive. Researchers were wondering whether rating agencies were villains, responsible for exacerbating the crisis, busting many companies and setting sovereign states on the verge of bankruptcy, or rather innocent messengers who were shot for bringing the bad news. Politicians have been trying to strengthen

Correspondence concerning this article should be addressed to: Alicja Malewska, Jesuit University Ignatianum in Krakow, Poland. E-mail: alicja.malevska@ignatianum.edu.pl the financial market with the help of reforms and to reduce power of the CRAs. Even the public opinion learned about the existence of the "Big Three", namely Moody's, S\&P and Fitch Ratings, which frequently hit the headlines and appeared in popular culture. On the other hand, in the period of economic turbulence, investors were more likely to depend on their own risk assessment and make decisions without waiting for credit rating agencies' announcements.

For the last decades, the list of critical arguments against the CRAs has been lengthening. The most common accusations were lack of transparency, potential conflict of interest (issuers must pay the CRAs to rate their securities), low quality of ratings, pro-cyclical behaviour, unreliable methodology, promoting neoliberalism as the only alternative for political economy, etc. This paper focuses on an- 
other major problem - oligopolistic structure of the credit rating market and its political consequences. The "Big Three" hold a collective global credit market share of more than $96 \%$ (more than $99 \%$ in case of government securities), leaving the competition far behind. One can even say that this is rather a duopoly, as the smallest among them - Fitch Ratings - holds less than 20\% (U.S. Securities and Exchange Commission, 2017).

The nature of oligopoly presents specific disadvantages for consumers and advantages for dominant firms. Entrepreneurs are able to set prices, which leads to maximization of their profits and potential loss of economic welfare to the society. Additionally, it has been proven that prices in oligopolies are sticky. Existing barriers to entry and cartel-like behaviour not only limit competition and consumer choice, but also reduce output (Krugman \& Wells, 2009). For the last decades, the "Big Three" have been making abnormal profits because of high level of concentration and have been abusing their market position in several ways. First of them was economic exploitation, but the second one was less obvious, as it was related to the political power of rating agencies. Due to various reasons, these private entities became influential actors on the international arena and do not hesitate to use this supremacy.

The recent crises exposed all weaknesses related to the CRAs position in the financial system and made clear that system-wide reforms were needed. In the US, it led to the introduction of Dodd-Frank Act Wall Street Reform and Consumer Protection Act in 2010, which brought significant changes to the financial services industry. Improvements to the regulations of credit rating agencies were among them. In the European Union, the financial crisis was followed by the deep sovereign debt crisis, so legislators and public opinion were more concerned about public finance sector. New rules were introduced in 2009 and subsequently revised in 2011 and 2013, after a series of sovereign ratings' downgrades (Bayar, 2014).

The aim of this study is to examine whether new regulations try to fight the problem of oligopoly in the credit rating market and to provide possible explanations of their efficiency. My argument is that so far, reforms were not effective in reducing oligopo- listic dominance of the "Big Three" and their political power, which are inextricably linked. To achieve this goal, I performed a case study of sovereign ratings segment of the market in the United States and in the European Union. Research is limited to those two actors, as only these seem to be powerful enough to change the rules of the international financial market. Other countries were also negatively affected by the actions of CRAs, but they are too dependent on credit ratings as the gateway to debt markets to have significant leverage on CRAs. I used content analysis of legal acts and other documents prepared by regulatory bodies, as well as descriptive statistical analysis of some economic indicators describing concentration rate in a market.

The first section of the paper gives a brief introduction of the research problem and outlines research questions. Then, literature review and pervasive theoretical frameworks are presented. The next part explains the rise of the "Big Three" and describes their oligopolistic dominance before the crises. The following section discusses the reforms regulating credit rating market in the U.S. and in the European Union. Then, an attempt to verify research hypothesis is made and the actual position of the CRAs with regulators' intentions are compared. Conclusions are drawn in the last section.

\section{Literature Review}

A great number of authors in literature has discussed credit rating agencies and their position in the financial market. Various approaches have been proposed to investigate position and effectiveness of CRAs since the 1990s. Many authors, mainly economists, were trying to determine the set of variables, taken into account in the rating process (Cantor \& Packer, 1996; Afonso, 2003; Haque et al., 1997). A very popular topic among scholars is the dependence between rating and yield spread or capital cost (Kliger \& Sarig, 2000; Kiff et al., 2012; White, 2009; Reisen \& von Maltzan, 1999). There is a considerable amount of literature on privileged position of the CRAs (Ferri et al., 1999; Hunt, 2009; Longstaff, 2010). More recent studies analyse the "Big Three" in terms of political economy, looking for sources of their power and explaining their influence in international relations (Sinclair, 2014; Partnoy, 
2009; Gaillard, 2011; Soudis, 2015). Multiple scholars have developed on methodology, rating process and its accuracy (Cantor \& Mann, 2007; Poon \& Firth, 2005; Cheng \& Neamtiu, 2009). In the last few years, many authors examined regulations of CRAs discussed and introduced after the crisis (Coffee, 2011; Opp et al. , 2013; Stolper, 2009; Partnoy, 2009; Dimitrov et al., 2015; Kruck, 2017).

Allegations against the "Big Three" are listed in almost every study on credit ratings. However, oligopolistic structure of credit rating market is very often mentioned as obvious shortcoming of this sector, without deeper reflection into that matter. Report "Study on the State of the Credit Rating Market" published by the European Commission in 2016 is an exception to this rule (European Commission, 2016). It provides extensive overview of measures introduced in the Credit Rating Agency Regulation (CRA3) and their potential impact on competition in the market. However, the more interesting part is the analysis of surveys and interviews conducted with CRAs, issuers and investors. The abovementioned report can only be considered a first step towards a more profound understanding of the current situation. The "Big Three" are US-based companies, so their market position cannot be examined without taking into account recent changes in American regulations.

Researchers analysing CRAs often focus on the economic dimension of oligopolistic dominance and tend to ignore the considerable political impact of credit ratings. Governments played a crucial role in shaping the very liberal global financial market and in enabling CRAs to become powerful players on the international arena. A Political Economy approach allows to analyse interrelationships between state and non-state actors in overlapping spheres of politics and economy.

There is still considerable uncertainty with regard to effectiveness of reforms aimed at limiting oligopoly in the credit rating market. The "Big Three" still seem to exploit market participants, especially smaller or poorer countries, which have no other choice but to use services of Moody's, S\&P or Fitch Ratings. To illuminate this uncharted area, I focused on a narrow segment of the credit rating market - sovereign and public finance ratings.

\section{Sources of Oligopolistic Dominance}

Oligopoly is defined as a market structure with few dominant firms. There are dozens of rating agencies all over the world, but the "Big Three" hold the biggest market share across different categories of ratings. Different methodologies can be applied to calculate the indicators (e.g., based on ratings number or revenues; HerfindahlHirschman Index ${ }^{1}$ or HHI Inverse), but all studies show similar results - the rating market is highly concentrated (Flynn \& Ghent, 2017; Gildehaus, 2012).

To explain the current situation, we should take a closer look at the sources of power of the "Big Three". In this case, we can distinguish two interdependent sources of legitimacy: legal regulations and investors' confidence. Before the 1970s, the activity of credit rating agencies was almost completely unregulated by law. Significantly, in that period common business model was investor-pay model, where agencies sold information about ratings to subscribing investors. That was their main source of revenue. At that time, credit rating market was competitive and financial success of firms issuing ratings was largely dependent on the quality and price of their product. First decades in the history of the credit rating shaped the market situation, where agencies with the largest reliability domination gained (Sylla, 2002).

We can point at two crucial changes in the 1970s. First was the shift from "investor-pay" to "issuer-pay" business model due to the rising cost of "free-riding". The new model solved this problem, but brought a new one - potential conflict of interest and risk of "ratingshopping" ${ }^{2}$. This decision was a key success factor and helped rating agencies to increase their revenues as well as influence in the rapidly growing market of financial securities. What is more, US Securities and Exchange Commission introduced the category of NRSRO (Nationally Recognised Statistical Rating Organization) in 1975. Ratings issued by agencies recognised as NRSROs could be used to assess the riskiness of securities for regulatory purposes (Commodity and Securities Exchanges, 1975). This category was incorporated in a number of state and federal level legal acts, regulating net capital requirements, investment and retirement funds or mortgage markets. In many cases, legislator required financial firms to use ratings from at least two NRSROs (Calabria \& Ekins, 2012). 
The idea behind the new regulation was to differentiate between institutions investing in safe and more risky securities. Companies focused on safe securities with very high ratings could be subject to reduced capital requirements. That was supposed to be a step towards greater flexibility of the financial market while protecting investors. However, the SEC choose a disputable way of regulating this market. At the beginning, it designated as NRSROs only the three biggest rating agencies - Moody's, Standard \& Poor's, and Fitch. Oligopolistic dominance of the "Big Three" was officially sanctioned. What is more, NRSRO designations were granted through sending a "No-Action Letter" by the SEC staff after assessing whether rating agency was in fact "nationally recognized"3. As a result, there were neither specific requirements to fulfil, nor common standards to be abided by the credit rating agencies interested in becoming NRSRO. Over the next two decades, the SEC bestowed this designation on just four rating agencies, but due to mergers in the 1990s, only the "Big Three" maintained their NRSRO status (U.S. Securities and Exchange Commission (SEC), 2003).

Status quo with legally sanctioned oligopoly lasted until the first decade of the 21th century. On one hand, NRSRO designation was granted to new, not only American rating agencies. On the other hand, a new law - the Credit Rating Agency Reform Act of 2006 - was adopted. It changed the existing approach, set certain guidelines and long list of requirements, which had to be met by an agency in order to be recognized as NRSRO (Credit Rating Agency Reform Act, 2006). The credit rating market was still highly oligopolistic, but at least barriers of entry were loosened up. It is worth noting that in the European Union, rating agencies were operating in legal vacuum during a long period. However, oligopoly was also sanctioned by transposing Basel II Accord (Basel Committee on Banking Supervision, 2004) to European law, as it forced financial institutions to use services of rating agencies (Regulation 575/2013).

Before proceeding to the next part of paper, where current situation and legal reforms are analysed, it is important to name the major characteristics of oligopolistic market structure. Its defining feature is a limited number of dominant competition participants. In this regard, credit rating industry is a model example - there are many agencies, but three of them have dominated the market. According to the European Securities and Markets Authority, S\&P issues $46.26 \%$ of ratings, Moody's - $31.27 \%$ and Fitch Ratings - 15.65\% (European Securities and Markets Authority (ESMA), 2017). Similar data is provided by SEC - S\&P, Moody's, and Fitch account for $96.4 \%$ of all the ratings outstanding (SEC, 2017).

In oligopoly, products may be more or less diverse. The "Big Three" offer very similar products: all of them rate financial institutions, insurance companies, corporate issuers, asset-backed securities, government securities etc. (Moody's Investors Service, 2018; S\&P Global Ratings, 2018; Fitch Ratings, 2018). Each company has its own methodology, which is not fully disclosed. However, their lists of criteria used in the rating process are quite similar as well (Moody's Investors Service, 2019; S\&P Global Ratings, 2018a; Fitch Ratings, 2018a). The literature provides us with evidence that ratings do not vary a lot across agencies - usually one or two notches on the scale (Hill et al., 2010). Very high similarity between ratings of different agencies can be observed, so we can assume there are no substantial differences in their methodologies.

Due to their dominant position in the market, oligopolists are often price setters. Ratings fees are not fully disclosed to the public, so their analysis is impossible. However, agencies publish limited information about the costs of their service: S\&P claims that minimum fee for corporate transaction and sovereign rating is $\$ 100,000$, for public finance issuer - from $\$ 7,500$ to $\$ 500,000$ (S\&P Global Ratings, 2018b). Moody's discloses its general range of fees: from $\$ 1,500$ to $\$ 2,500,000$ (Moody's Investors Service, 2018). Fitch admits that the clients should pay from $\$ 1,000$ to US\$750,000 per issue (Fitch Ratings, 2018b). Fees differ depending on amount of debt issuance, category of issuer, product type and complexity. This is typical example of price discrimination, when a company charges different prices for largely similar products in order to maximize profit. Price discrimination is not possible in perfect competition where companies are price-takers.

Oligopoly in the credit rating market meant not only abnormal economic profit for the "Big Three". Countries interested in borrowing money were forced to become credit rating agencies' clients, because ratings happened to be unsubstitutable. In the twentieth century, 
ratings became the gateway to the international financial market for many young countries with short credit history, because investors relied on assessment of rating agencies in their investment decisions. It may look like a win-win situation for both sides of the transaction. However, there is a correlation between the cost of borrowing money and rating of the issuer - downgrades of ratings are often accompanied by rise in bond spreads (Candelon et al., 2011; Goh \& Ederington, 1993). Additionally, the aforementioned regulations specified what categories of ratings could be in the portfolio of some institutional investors, e.g. pension funds (Commodity and Securities Exchanges, 1975). Whenever sovereign rating was downgraded to a speculative-grade, it had to be automatically sold by such investor, what could possibly lead to another rise of spread.

As mentioned before, the methodology of rating process before the reform was not disclosed. What is more, in case of sovereign ratings, qualitative factors seemed to have serious impact on the output. According to some authors, the performance of the "Big Three" showed that liberal economic policy was preferred and rewarded by higher ratings. And conversely, there is evidence of discrimination according to the ideology or economic reforms that did not follow the Washington consensus (Barta \& Johnston, 2018; Tennant \& Tracey, 2016). It raised pressure to adjust to the promoted economic policy if a country was in need to raise capital. In a perfectly competitive market, government would be able to choose among different agencies, using different or unbiased methodologies. The highly oligopolistic structure of the credit rating market left no choice. Barriers of entry, created by legal regulations and investors' trust led to the situation where private firms were able to dictate sovereign governments how to design their economic policy or - as many critics claimed - even increase the probability of default.

\section{Reforms of the Credit Rating Sector after the Crises}

The situation on the credit probably market would not change much if it were not for the last global crisis. Firstly, the "Big Three" failed to assess the real risk of complex securities of structured finance. Mortgagebased securities and collateralized debt obligations worth billions of dollars received overgenerous ratings and had to be downgraded to junk status a few years later (National Commission on the Causes of the Financial and Economic Crisis in the United States, 2011; Hill, 2009). Initially, highly rated securities were bought by a wide range of financial institutions, including pension funds and money market funds, which, according to the law, could invest only in safe securities. Credit rating agencies were accused of accelerating the recession, because impaired securities spread a financial crisis to the real economy in the US and around the world (Partnoy, 2009; Hunt, 2009; Hill, 2009).

The second wave of criticism followed when the euro zone sovereign debt crisis broke. Over a six-year period, rating agencies changed ratings of the European countries more than 100 times and that was mostly downgrades (European Rating Platform, 2018). It resulted in abrupt bond sell-offs and increase in borrowing cost for all affected states. Some of them were already in a deep phase of downturn and lower ratings pushed them into a dangerous debt spiral. In case of Greece, it even led to bankruptcy. It is worth mentioning that before the crisis, Greece was rated at A-level with positive or stable outlook by all three rating agencies (Greece - Credit Rating, 2018). Issuers rated with this level are described as credible debtors with very low probability of default.

Severe rating changes affected not only PIIGS countries with obvious problems in the public finance sector, but also countries traditionally perceived as stable and reliable, such as France or Austria (Schneider \& Cody, 2012). The size and impact of the crisis and frequent, sometimes groundless downgrades triggered a heated debate about the role and position of credit rating agencies in Europe.

American response to the turbulence in the financial markets was the Dodd-Frank Wall Street Reform and Consumer Protection Act adopted in 2010. It introduced a number of new regulations concerning NRSROs, including annual detailed reports, internal control, fines and penalties, disclosure of rating methodologies, eliminating the threat of conflict of interest. What is more, this act required to remove requirement of reliance on or any reference to credit ratings from federal and state level regulations. In section 931, the regulator emphasized the importance of CRAs: "Because of the systemic importance of credit ratings and the reliance placed on credit ratings by individual and 
institutional investors and financial regulators, the activities and performances of credit rating agencies, including nationally recognized statistical rating organizations, are matters of national public interest, as credit rating agencies are central to capital formation, investor confidence, and the efficient performance of the United States economy”. This statement was followed by an explanation why new regulations were needed: "In the recent financial crisis, the ratings on structured financial products have proven to be inaccurate. This inaccuracy contributed significantly to the mismanagement of risks by financial institutions and investors, which in turn adversely impacted the health of the economy in the United States and around the world" (Wall Street Reform and Consumer Protection Act, 2010). Therefore, the oligopolistic structure of the market was not directly mentioned in the reform. However, the obligation to eliminate references to credit rating agencies can be interpreted as an attempt to take away some power from the "Big Three".

In 2018, President Trump signed into law The Economic Growth, Regulatory Relief and Consumer Protection Act, the first major bill regulating financial market since the Dodd-Frank Act. Many provisions of the new act repeal the 2010's law prohibitions and ease certain regulations. However, reforms did not cover rules governing credit ratings agencies ${ }^{4}$.

The Dodd-Frank Act was a complex reform of the whole financial market in the US, containing hundreds of mandatory rulemaking provisions. In the European Union, this process was longer and reforms were introduced in a few consecutive steps. Analysing the timeline of the crisis and schedule of new rules' implementation leads to the conclusion that the law was designed and adopted ad hoc, in response to the current situation. Parliamentary debates on projects regulating rating agencies also reflected rush and emotional attitude towards these subjects. The first package of rules, which was introduced in 2009, obliged external rating agencies to register in any Member State and subject to its internal oversight regime. There were also provisions regarding transparency, avoiding conflicts of interest and publishing more detailed description of rating methodology. Additional requirements were directed towards issuing ratings of structured financial instruments and unsolicited ratings (Regulation 1060/2009 ). New regulation had to create a legal framework for the CRAs, at the same time protecting investors' interests. As we can see, it did not refer to the oligopoly, sovereign ratings or overdependence on ratings, because it was introduced just before the beginning of the euro zone crisis.

It turned out soon that the first set of rules was not enough to overcome problems related to the credit rating market. The amendment was adopted in 2011 and the main novelty was the creation of the European Securities and Markets Authority (ESMA), established to safeguard the stability of the financial markets. The new institution took over all responsibilities related to registering and supervision of CRAs and trade repositories ratings (Regulation 1095/2010). The European legislator tried to gain control over the credit rating market and US-based agencies. However, the requirements for registration created potential barriers for entry and did nothing to prevent the oligopoly.

The last amendment was made in 2013 and is known as CRA3 Regulation. This legislative package was focused on issuing sovereign ratings, further improving the quality of the rating process, reducing over-reliance on credit ratings and enhancing competition in this market. A number of measures was introduced to limit oligopolistic dominance of the "Big Three", including the requirement to appoint at least two independent CRAs for structured finance instrument and to consider one of them to be a small CRA (no more than $10 \%$ of the total market share). The regulator also tried to neutralize the political power of the "Big Three" by prohibiting any direct opinions on national policies: "direct or explicit requirements or recommendations from credit rating agencies to sovereign entities as regards those policies should not be allowed. Credit rating agencies should refrain from any direct or explicit policy recommendations on policies of sovereign entities" ratings (Directive 2013/14/ EU, Regulation 462/2013).

\section{Competition in the Credit Rating Market after the Reforms}

Both American and European regulations were aimed at limiting the oligopolistic dominance of the "Big Three" in the credit rating market. They have been in a force for a few years now, so some conclusions can be already drawn and first assessment of their effectiveness can be done. In this paper, I focus 
Table 1. HHI Inverse for government securities market segment according to SEC

\begin{tabular}{lccccccccc}
\hline Year & 2008 & 2009 & 2010 & 2011 & 2012 & 2013 & 2014 & 2015 & 2016 \\
\hline HHI Inverse & 2.83 & 2.65 & 2.69 & 2.47 & 2.50 & 2.46 & 2.40 & 2.40 & 2.40 \\
\hline
\end{tabular}

Source: U.S. Securities and Exchange Commission (2017), p. 13.

Table 2. HHI Inverse for sovereign and public finance market segment according to ESMA

\begin{tabular}{lccc}
\hline Year & 2014 & 2015 & 2016 \\
\hline HHI Inverse & 2.85 & 2.84 & 3.12 \\
\hline
\end{tabular}

Source: European Commission (2016), p. 30; own calculations.

on political power of rating agencies, so I will examine the current state of the segment of government ratings.

In 2017, there were 10 rating agencies registered as NRSROs in the US, eight of them were US-based, one from Mexico and one from Japan. S\&P issued $53.3 \%$ of government ratings, Moody's $-34.7 \%$ and Fitch Ratings - $11.1 \%$, accounting for $99.1 \%$ of the total (SEC, 2017). Table 1 presents the results of $\mathrm{HHI}$ Inverse $^{5}$, used to measure industry competition, in the recent years (the more concentrated the market, the lower HHI Inverse).

As shown in the Table 1, concentration in this market segment is constantly growing despite the new regulations. Oligopoly is even stronger than it was in 2008, at the peak of the financial crisis. One way of explaining this paradox is assuming that American reforms were aimed at the quality of corporate and structured instruments' ratings, whereas government ratings were left aside. Another possible explanation is that American regulator is using CRAs as an instrument of power in international relations. The "Big Three" reward liberal economies with higher ratings, simultaneously strengthening the dominance of western economic system and protecting American investors' interests.

There are 45 entities registered as credit rating agencies in the European Union. The high number of market participants may be illusive, because credit ratings market is also divided between the "Big Three". Eleven agencies issue sovereign ratings, but
Moody's holds $40 \%$ of market revenues, Fitch and S\&P - 28\% each. It accounts for $96.41 \%$ of all ratings in category. This means that the remaining eight agencies, which issue sovereign and public finance ratings, hold less than $4 \%$ of this market segment (European Commission, 2016). The results of HHI Inverse are presented in Table 2 (data before 2014 is not publicly available).

The growth in the HHI Inverse means the concentration in the market was slightly lower in 2016. It is a modest success of the efforts to disempower the "Big Three" on the European financial market. However, without any doubts, it is still an oligopolistic market.

The most effective way of fighting oligopoly is to reduce barriers of entry. In the US, an important barrier was removed in 2006, when the list of requirements for NRSRO designation was finally introduced. Further reforms - the Dodd-Frank Act and CRA3 in the EU - reduced any reference to the NRSRO or any other specific agencies and encouraged internal credit assessment. The main goal was to let other competitors to gain market share and reduce dominance of the "Big Three".

On the other hand, new regulations related to increased supervision of the CRAs created a long list of requirements to be met. Some of them are quite costly, because additional staff or resources are necessary (having an independent review board, compliance officer, record keeping). In the EU, rating agencies are also obliged to bear regulatory and administrative fees (CRAs whose revenues are higher than 10 million 
euros pay an annual supervisory fee to ESMA). These costs can act as a barrier of entry for small or new credit rating agencies, favouring the biggest agencies.

One could argue that sovereign ratings are not essential for CRAs, as they earn much more by rating corporate bonds and structured finance instruments. However, this category stands for $11 \%$ of revenue related to issuing ratings, which is more than 100,000,000 euro annually (European Commission, 2016). In 2017, S\&P rated 131 sovereigns - 20 more than decade ago (Positive Signals for Sovereign Ratings, 2018). Moody's rates 138 sovereigns and even more if country ceilings are taken into account (Sovereigns Supranational Rating List, 2018). This shows that despite growing criticism regarding that quality of ratings, governments still voluntarily use services of the biggest rating agencies, because it is expected by financial markets. In such circumstances, the oligopolistic dominance of the "Big Three" is unthreatened and their impact as powerful non-majoritarian institution is still significant.

\section{Conclusions}

Oligopoly is a market structure with some clear disadvantages for consumers, like offering fewer choices, eliminating motivation to compete or creating barriers of entry for new businesses. All these characteristics can be found in the credit rating market. As a result, we can observe the social welfare loss. On the other hand, the "Big Three" not only enjoy the benefit of abnormal gains, but also become influential subject in international relations. They have the power to assess credibility of sovereign countries and their economic policy, what is related to a significant impact on public borrowing costs. The biggest CRAs are no longer just gatekeepers protecting participants of the financial market from speculative securities. These private entities can influence governments or other public authorities to change their economic policy in order to receive higher rating.

Reforms introduced after the crises in the US and in the EU brought intensified supervision and reduction of over-reliance on ratings. However, methods aimed at increasing competition in the market and fighting oligopoly seem to be inefficient. Encouraging new entities to join the market does not solve the problem, because investors still tend to trust old agencies with long history, forgetting about their failures. After decades of holding a privileged position in the market and being sanctioned oligopolists, Moody's, S\&P and Fitch Ratings leave their competitors far behind. The capital trust accumulated during the last 40 years cannot be easily changed by removing any reference to the ratings in new regulations. On the other hand, alternative ideas, like calls for creating public credit rating agencies, do not solve the problem either. A public rating agency would have to face the same challenges - lack of reputation among investors or potential conflict of interests.

There are two most probable explanations of the hitherto failure in limiting oligopolistic dominance and political power of the "Big Three". First, one implies that credit rating market is an investor-driven natural oligopoly (OECD, 2010). In such market structure, small number of competitors is enough to provide needed services (this can be easily applied to sovereign and public ratings segment, where number of issuers is very limited). CRAs built their market position thanks to reducing information complexity and asymmetry by offering simple and widely recognised letter symbols. The biggest CRAs offer very similar and easily comparable rating systems, which apply to financial instruments or issuers regardless their size, type or geographical location. Investors value this simplicity, which shortens decision-making process, so they are not interested in analysing and interpreting ratings from numerous competing agencies (Schroeter, 2013). Natural oligopoly theory has solid arguments in its favour, but does not explain why key participants of credit rating market did not change even after facing serious loss of reputation, which was a result of poor performance during financial crises of the last decades.

The second explanation appeals to the realist school of hegemonic stability theory. In a mixed model of this theory, the hegemon is portrayed as "seeking both general and personal benefits, and as relying on both threats and rewards to achieve its goals" (Cohn, 2012). The "Big Three" of CRAs are US-based institutions promoting liberal world order with dominant neoclassical economy approach. They have certain ideological power exercised by punishing and rewarding those who break or obey the rules of the Washington consensus. For governments around the world, higher rating means easier and cheaper access to capital in international financial market. From the perspective of the United States, this is a useful instrument of forging and maintaining international capitalist system. Consequently, American inves- 
tors' interests are protected by the oligopolistic credit rating market, so the US regulator does not have sufficient incentives to break up this oligopoly. This hypothesis was confirmed by the Dodd-Frank Wall Street reform, which focused on improving quality of credit ratings, but ignored problem of the oligopoly to a large extent. On the other hand, recent credit rating regulations adopted in the European Union have limited effect, because American dominance in financial market is still incontestable. The "Big Three" still have ability to punish sovereign governments by downgrading their ratings. In extreme circumstances, like deep financial crisis, this may even lead to a situation where rating agencies have indirect power to change the course of country's economic policy.

The analysis proved that the "Big Three" did not lose its oligopolistic power after crises, huge criticism and legal reforms. All the measures introduced in the US and EU were not sufficient to change the status quo in the market and to regain control over it. These findings suggest that the only effective factor changing market structure may be time, so further research should be undertaken in a few years.

\section{References}

Afonso, A. (2003). Understanding the determinants of sovereign debt ratings: Evidence for the two leading agencies. Journal of Economics and Finance, 27(1), 56-74. https://doi.org/10.1007/ BF02751590

Barta, Z., \& Johnston, A. (2018). Rating politics? Partisan discrimination in credit ratings in developed economies. Comparative Political Studies, 51(5), 587-620. https://doi. org/10.1177/0010414017710263

Basel Committee on Banking Supervision (2004). Basel II: International convergence of capital measurement and capital standards: A revised framework. https://www.bis.org/publ/bcbs128.htm

Bayar, Y. (2014). Recent financial crises and regulations on the credit rating agencies. Research in World Economy, 5(1), 49-58.

Benmelech, E., \& Dlugosz, J. (2010). The credit rating crisis. NBER Macroeconomics Annual, 24(1), 161208. https://doi.org/10.1086/648293

Calabria, M., \& Ekins, E. (2012). Regulation, market structure, and role of the credit rating agencies. Cato Institute Policy Analysis No. 704.

Candelon, B., Sy, M. A. N., \& Arezki, M. R. (2011). Sovereign rating news and financial markets spillovers: Evidence from the European debt crisis (IMF
Working Paper No. 11/68). International Monetary Fund. https://ssrn.com/abstract=1802981

Cantor, R., \& Mann, C. (2007). Analyzing the tradeoff between ratings accuracy and stability. Journal of Fixed Income, 16(4), 1-8. https://doi.org/10.3905/ jfi.2007.683318

Cantor, R., \& Packer, F. (1996). Determinants and impact of sovereign credit ratings. The Journal of Fixed Income, 6(3), 37-54. https://doi.org/10.3905/ jfi.1996.408185

Cheng, M., \& Neamtiu, M. (2009). An empirical analysis of changes in credit rating properties: Timeliness, accuracy and volatility. Journal of Accounting and Economics, 47(1-2), 108-130. https:/doi. org/10.1016/j.jacceco.2008.11.001

Coffee Jr, J. C. (2011). Ratings reform: The good, the bad, and the ugly. Harvard Business Law Review, 1, 231- 279 .

Commodity and Securities Exchanges, 17 C.F.R. $\$$ 240.15c3-1 (1975). https://www.govinfo.gov/app/ details/CFR-2017-title17-vol2/context

Credit Rating Agency Reform Act of 2006, 109th Cong. (2005-2006). https://www.congress.gov/bill/109thcongress/senate-bill/3850

Dimitrov, V., Palia, D., \& Tang, L. (2015). Impact of the Dodd-Frank act on credit ratings. Journal of Financial Economics, 115(3), 505-520. https://doi. org/10.1016/j.jfineco.2014.10.012

Dodd-Frank Wall Street Reform and Consumer Protection Act, Pub. L. No. 111-203, 124 Stat. 1376. (2010).

European Commission. (2016). Study on the state of the credit rating market: Final report. https://op.europa. eu/en/publication-detail/-/publication/38a23d36f63e-11e5-8529-01aa75ed71a1/language-en

Regulation 1060/2009. Credit rating agencies. European Parliament, Council of the European Union. http:// data.europa.eu/eli/reg/2009/1060

Regulation 1095/2010. Establishing a European Supervisory Authority (European Securities and Markets Authority), amending Decision No 716/2009/EC and repealing Commission Decision 2009/77/EC. European Parliament, Council of the European Union. http://data.europa.eu/eli/reg/2010/1095

Directive 2013/14/EU. Amending Directive 2003/41/ $E C$ on the activities and supervision of institutions for occupational retirement provision, Directive 2009/65/EC on the coordination of laws, regulations and administrative provisions relating to undertakings for collective investment in transferable securities (UCITS) and Directive 2011/61/EU on Alternative Investment Funds Managers in respect of over-reli- 
ance on credit ratings. European Parliament, Council of the European Union. http://data.europa.eu/eli/ $\operatorname{dir} / 2013 / 14$

Regulation 462/2013. Amending Regulation (EC) No 1060/2009 on credit rating agencies. European Parliament, Council of the European Union. http:// data.europa.eu/eli/reg/2013/462

Regulation 575/2013. On prudential requirements for credit institutions and investment firms and amending Regulation (EU) No 648/2012. European Parliament, Council of the European Union. http://data. europa.eu/eli/reg/2013/575/oj

European Securities and Markets Authority. (2017). Report on CRA market share calculation. https:// www.esma.europa.eu/sites/default/files/library/2015-1879_esma_cra_market_share_calculation.pdf

Ferri, G., Liu, L. G., \& Stiglitz, J. E. (1999). The procyclical role of rating agencies: Evidence from the East Asian crisis. Economic Notes 28(3), 335-355. https:// doi.org/10.1111/1468-0300.00016

Financial CHOICE Act of 2017, H.R. 10, 115th Cong. (2017-2018). https://www.congress.gov/bill/115thcongress/house-bill/10

Fitch Ratings. (2018a). Rating Criteria [Data set]. https:// www.fitchratings.com/site/criteria.

Fitch Ratings. (2018b). Terms of Use. https://www.fitchratings.com/site/about/terms.

Flynn, S. \& Ghent, A. (2017). Competition and credit ratings after the fall. Management Science 64(4), 167292. https://doi.org/10.1287/mnsc.2016.2604

Gaillard, N. (2011). A century of sovereign ratings. Springer Science \& Business Media.

Gildehaus, H. (2012). The rating agency oligopoly and its consequences for European competition law. European Law Review, 3, 269-293.

Goh, J. C., \& Ederington, L. H. (1993). Is a bond rating downgrade bad news, good news, or no news for stockholders? The Journal of Finance, 48(5), 20012008. https://doi.org/10.1111/j.1540-6261.1993. tb05139.x

Haque, N. U., Mathieson, D., \& Mark, N. (1997). Rating the raters of country creditworthiness. Finance and Development, 34(1), 10-13.

Hill, Claire A. (2009) Why did rating agencies do such a bad job rating subprime securities. University of Pittsburgh Law Review, 71, 585-608.

Hill, P., Brooks, R., \& Faff, R. (2010). Variations in sovereign credit quality assessments across rating agencies. Journal of Banking \& Finance, 34(6), 1327-1343. https://doi.org/10.1016/j.jbankfin.2009.11.028
Hunt, J. P. (2009). Credit rating agencies and the worldwide credit crisis: the limits of reputation, the insufficiency of reform, and a proposal for improvement. Columbia Business Law Review, 1, 109-209.

Kiff, J., Nowak, S. B., \& Schumacher, L. (2012). Are rating agencies powerful? An investigation into the impact and accuracy of sovereign ratings (Working Paper no. 12/23). International Monetary Fund.

Kliger, D., \& Sarig, O. (2000). The information value of bond ratings. The Journal of Finance, 55(6), 28792902. https://doi.org/10.1111/0022-1082.00311

Kruck, A. (2017). Asymmetry in empowering and disempowering private intermediaries: The case of credit rating agencies. The ANNALS of the American Academy of Political and Social Science, 670(1), 133151. https://doi.org/10.1177/0002716217691459

Krugman, P., \& Wells, R. (2009). Microeconomics. Worth.

Longstaff, F. A. (2010). The subprime credit crisis and contagion in financial markets. Journal of Financial Economics, 97(3), 436-450. https://doi. org/10.1016/j.jfineco.2010.01.002

Moody's Investors Service. (2018). Policy for Disclosures. MIS Compliance Department. https://www. moodys.com/uploadpage/Mco\%20Documents/ Policy_for_Disclosures.pdf

Moody'sInvestorsService.(2019). RatingMethodologies. https://www.moodys.com/researchandratings/ methodology/003006001/ratingmethodologies/ methodology/003006001/4294966628/4294966848

National Commission on the Causes of the Financial and Economic Crisis in the United States. (2011). The Financial Crisis Inquiry Report. Financial Crisis Inquiry Commission. https://www.govinfo.gov/ content/pkg/GPO-FCIC/pdf/GPO-FCIC.pdf

Organisation for Economic Cooperation and Development. (2010). Competition and Credit Rating Agencies. https://www.oecd.org/daf/competition/ sectors/46825342.pdf

Opp, C. C., Opp, M. M., \& Harris, M. (2013). Rating agencies in the face of regulation. Journal of Financial Economics, 108(1), 46-61. https://doi. org/10.1016/j.jfineco.2012.10.011

Partnoy, F. (2009). Overdependence on credit ratings was a primary cause of the crisis. In D. D. Evanoff, P. Hartmann, \& G. G. Kaufman (Eds.), The first credit market turmoil of the 21st century: Implications for public policy (pp. 175-191). World Scientific.

Poon, W. P., \& Firth, M. (2005). Are unsolicited credit ratings lower? International evidence from bank ratings. Journal of Business Finance \& Account- 
ing, 32(9-10), 1741-1771. https://doi.org/10.1111/ j.0306-686X.2005.00646.x

Reisen, H., \& Von Maltzan, J. (1999). Boom and bust and sovereign ratings. International Finance, 2(2), 273293. https://doi.org/10.1111/1468-2362.00028

Rhoades, S. A. (1993). The Herfindahl-Hirschman index. The Federal Reserve Bulletin 79, 188.

S\&P Global Ratings. (2018a). Ratings criteria. https://www. standardandpoors.com/en_US/web/guest/ratings/ ratings-criteria/-/articles/criteria/general/filter/all.

S\&P Global Ratings. (2018b). U.S. ratings fees disclosure. https://www.standardandpoors.com/en_US/delegate/getPDF? articleId=1976812\&type=COMMENTS\&subType=REGULATORY.

Schneider, H., \& Cody, E. (2012, January 13). France loses $A A A$ in euro downgrade. Washington Post. https:// www.washingtonpost.com/business/economy/ france-loses-aaa-in-euro-downgrade/2012/01/13/ gIQAxALzwP_story.html?noredirect=on\&utm_ term $=.8 \mathrm{~b} 155117 \mathrm{f} 7 \mathrm{~d} 9$.

Schroeter U.G. (2013). Credit ratings and credit rating agencies. In: G. Caprio, D. W. Arner, T. Beck, C. W. Calomiris, L. Neal, \& N. Véron, (Eds.) Handbook of key global financial markets, institutions, and infrastructure (pp. 379-390). Academic Press.

Sinclair, T. J. (2014). The new masters of capital: American bond rating agencies and the politics of creditworthiness. Cornell University Press.

Soudis, D. (2015). Credit rating agencies and the IPE: Not as influential as thought? Review of International Political Economy, 22(4), 813-837. https://doi.org/ 10.1080/09692290.2014.957234

Stolper, A. (2009). Regulation of credit rating agen-

\section{Endnotes:}

1. „The Herfindahl-Hirschman Index is a statistical measure of concentration. (...)The HHI accounts for the number of firms in a market, as well as concentration, by incorporating the relative size (that is, market share) of all firms in a market." (Rhoades, 1993, p.79).

2. Rating-shopping is a situation when "issuers shop around among rating agencies for the highest rating, which might have led to inflated ratings" (Benmelech \& Dlugosz, 2010, p. 162).

3. "An individual or entity who is not certain whether a particular product, service, or action would constitute a violation of the federal securities law may request a "no-action" letter from the SEC staff." No cies. Journal of Banking \& Finance, 33(7), 12661273. https://doi.org/10.1016/j.jbankfin.2009.01.004 Sylla, R. (2002). An historical primer on the business of credit rating. In R. M. Levich, G. Majnoni, \& C. Reinhart (Eds.), Ratings, rating agencies and the global financial system (pp. 19-40). Springer US.

Tennant, D.F., \& Tracey, M.R. (2016). Sovereign debt and credit rating bias. Palgrave Pivot.

The Economic Growth, Regulatory Relief, and Consumer Protection Act, 115th Cong. (2017-2018). https:// www.congress.gov/bill/115th-congress/senatebill/2155

U.S. Securities and Exchange Commission. (2003). Report on the Role and Function of Credit Rating Agencies in the Operation of the Securities Markets. https://www.sec.gov/news/studies/credratingreport0103.pdf.

U.S. Securities and Exchange Commission. (2017). Annual Report on Nationally Recognized Statistical Rating Organizations. https://www.sec.gov/ocr/reportspubs/annual-reports/2017-annual-report-onnrsros.pdf.

White, L. J. (2009). The Credit-Rating Agencies and the Subprime Debacle. Critical Review, 21(2-3), 389-399.

Action Letters, http://www.sec.gov/answers/noaction.htm.

4. The oligopolistic structure of credit rating agency market was directly addressed in the Financial CHOICE Act of 2017, which was passed by the House of Representatives, but died on the Senate floor, as the bill received only partisan support. https://www.congress.gov/bill/115th-congress/ house-bill/10.

5 The inverse of the HHI ("HHI Inverse") can be used to represent the number of firms with equal market share necessary to replicate the degree of concentration in a particular industry. 